\title{
Social Transformation: Education and Employment- Unemployment Scenario in North East India
}

\author{
Ms. Sonam Arora \\ Ph. D. Scholar, National Institute of Educational Planning and Administration, India 110016, \\ DOI: 10.29322/IJSRP.10.05.2020.p10136 \\ http://dx.doi.org/10.29322/IJSRP.10.05.2020.p10136
}

\begin{abstract}
Societies everywhere are undergoing social transformation making it essential to bring in the new forms of education to foster competencies that economies need, today and tomorrow. Education is termed as "common good" by UNESCO and is regarded as the key to achieve sustainable development in a society as it is an investment in human capital. The changing demographics profile of India makes it the largest country with youth population with $62.5 \%$ of its population in the working age. Thomas Piketty (2014) observes that economic growth always includes a purely demographic component and a purely economic component. In order to harness power of the demographic component which has created an economic superpower in the form of enormous labour supply, the employment-unemployment scenario has to be addressed. The education and employment matrix needs to be understood, strengthened and made responsive to economic growth to adapt to the rapid changes that are happening worldwide. The North Eastern Region (NER) of India is backward in terms of economic indicators. In order to assess progress of NER, the paper attempts to examine the trends in the education sector, explore the employment-unemployment scenario of higher education graduates in the eight states. The paper draws a micro-economic analysis of historical data to identify the better and worse performing states in the NER according to the indicators of social transformation through a state wise analysis approach. The paper attempts to gauge the areas where the states need to work in order to achieve social transformation in the long run.
\end{abstract}

Index Terms- social transformation, higher education, employment, North East Region, India

\section{INTRODUCTION}

E mployment is a key parameter of development and skilled employment is an outcome of education. The study of employment and education is an important aspect to understand the performance of individuals (at micro level), society (at meso level) and economy (at macro level). The North Eastern Region (NER) of India is highly diverse and vibrant but still remains underdeveloped as compared to the other states of India. According to the world bank report, India's NER could be seen as a victim of a low-level equilibrium where poverty and lack of development lead to civil conflicts, lack of belief in political leadership and government, and, therefore, to a politically unstable situation. This, in turn, leads to further barriers to poverty reduction, accelerated development and growth." (World Bank,
2007). As education is termed as "common good" and an investment in the human capital (UNESCO) and is regarded as the key to achieve sustainable development in a society, it is only through education that these states can be uplifted and transformed in all aspects. As it has been pointed out by Prof. D.S.Kothari, an eminent Indian educationist, "Knowledge is vitally important, but if it is to transform society from a state of relative stagnation to one of dynamism and progress, there must be a general willingness and determination to make use of it in the service of the community", education is an important tool for both accumulation of social assets and formation of social capital (Nayar, 2004).

Social transformation is defined as the process in which society changes due to various factors like economic growth, employment creation and educational development which ultimately impacts people's interactions and lifestyle by way of changing their social status in the long run. It is therefore, in this context, necessary to work on the identified areas to transform the society at a macro level. Hence, the circular flow of educationemployment-social transformation is the way an economy progresses and that shall become foundation nations economic and social policies.

\section{THEORETICAL BACKGROUND}

Agrarian distress and rural unemployment have always been a concern in the Indian economy. With the 1991 reforms, inclusive growth became the theme of development. It is in this context of development, it has to be realized that education and employment are interconnected and cannot be seen in isolation as the triggers of social transformation in any society (figure 1).

Figure 1: Social Transformation in an economy 


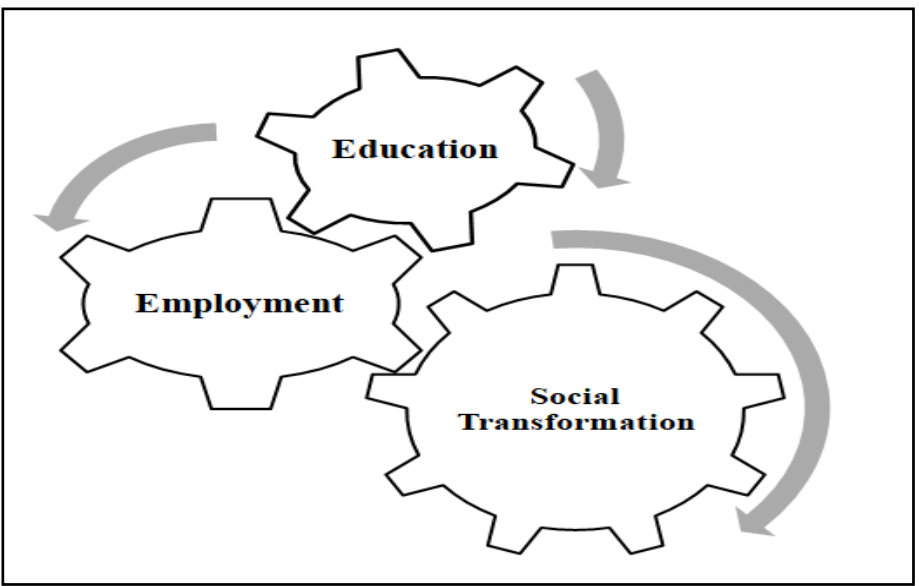

Source: Author's construct based on literature review

Economic development and growth are the two key terms used to ascertain progress of any economy. Every economy is run by its population so, it becomes reasonable to say "skilled population are the drivers of an economy's growth in the long run". Eric A. Hanushek establishes a strong relationship between human capital and economic growth. He uses the experiences of "Latin America Growth Puzzle" and "East Asian Miracle" to explain that high human capital and high growth of a country are related. Quite a few economic theories have been devised on the importance of education to help transform resources into productive inputs. A few are explained below: First, the human capital theory puts students as resources that can be made productive through investments in their human capital formation that includes development and enhancing their skills through education. Second, the sheepskin version of screening hypothesis implies that wages will rise faster with extra years of education when this extra year of education is with a certificate. In other words, the number of years spent in education is used as a signaling device that employers use to select the more skilled worker. Third, the bumping theory states that in order to reduce the recruitment costs, employers rely on level of education to screen the applications at the initial stage of recruitment process. More educated stand at the front row for jobs in the labor market while less educated are pushed backward. Fourth, the job ladder model explains that employers follow preferential hiring practices in which they wish to employ highly educated people. This means high levels of education are important to fetch employment in the labor market.

\section{Objectives, Database AND Methodology}

The objectives of the study are:

1. To examine the trends in education in the NER of India.

2. To explore employment-unemployment of scenario in general and at graduate and above level of education in NER of India.

3. To identify the top and bottom performing states with reference to the indicators of social transformation.

The study is based on secondary data sources as it uses data from Employment-unemployment surveys conducted by the National Sample Survey Organization (NSSO), Periodic Labour Force Survey (PLFS), All India Survey on Higher Education (AISHE), Unified District Information on School Education (UDISE) and other reports, publications, articles from various organizations. The data on employment is taken for all workers (usual status and subsidiary status). The study brings out an economic analysis of historic data using a state wise approach for the eight states in the NER of India. It has been found that the increasing share of jobseekers is with graduate and above degrees (Khare, 2014) therefore, emphasis is laid on graduate \& above level of education.

\section{ANALYSIS}

The findings of data analysis are discussed below:

\subsection{Trends in Education across the states}

\subsubsection{School Education}

The drop-out rates have been consistently falling at all the levels of education since 2014. At primary level of education, a sharp rise is observed in Arunachal Pradesh after Manipur and Meghalaya. A high drop rate has existed in all other states from 2014 to 2016. At upper primary level of education, a sharp rise is observed in Meghalaya and Nagaland. At secondary level of education, a sharp rise is observed in Meghalaya, Mizoram and Sikkim. In the year 2016-17, the drop-rate is the highest in the state of Arunachal Pradesh (primary), Nagaland (upper primary) and Mizoram (secondary). Assam is the only state for where the dropout rates have fallen down for all the levels of education and Nagaland is the state where it has gone down for secondary level of education (see table 1).

Table 1: Drop-out Rates in Education

\begin{tabular}{|l|l|l|l|l|l|l|l|l|l|}
\hline \multirow{2}{*}{ State } & \multicolumn{3}{|l}{ Primary } & \multicolumn{3}{l|}{ Upper Primary } & \multicolumn{2}{l|}{ Secondary } \\
\cline { 2 - 11 } & $\begin{array}{l}2014- \\
15\end{array}$ & $2015-16$ & $2016-17$ & $2014-15$ & $2015-16$ & $2016-17$ & $2014-15$ & $\begin{array}{l}2015- \\
16\end{array}$ & $\begin{array}{l}2016- \\
17\end{array}$ \\
\hline $\begin{array}{l}\text { Arunachal } \\
\text { Pradesh }\end{array}$ & 10.89 & 10.82 & 23.25 & 5.59 & 6.71 & 12.81 & - & 17.11 & 29.93 \\
\hline Assam & 7.44 & 15.36 & 5.6 & 7.05 & 10.51 & 2.51 & 30.43 & 27.06 & 27.6 \\
\hline Manipur & 18 & 9.66 & 16.79 & 7.02 & 4.2 & 12.76 & 13.81 & 14.38 & 21.05 \\
\hline
\end{tabular}




\begin{tabular}{|l|l|l|l|l|l|l|l|l|l|} 
Meghalaya & 10.34 & 10.34 & 17.69 & 6.84 & 6.52 & 17.59 & 8.47 & 20.52 & 28.07 \\
\hline Mizoram & 12.96 & 12.96 & 15.36 & 6.02 & 4.78 & 9.88 & 18.7 & 21.88 & 30.67 \\
\hline Nagaland & 19.41 & 19.41 & 20.95 & 17.86 & 7.92 & 18.28 & 35.11 & 18.23 & 29.88 \\
\hline Sikkim & 4.57 & 4.57 & 5.13 & 5.14 & 1.57 & 7.64 & 12.89 & 15.89 & 24.15 \\
\hline Tripura & 3.58 & 3.58 & 4.39 & 2.72 & 1.99 & 5.34 & 23.97 & 28.42 & 29.76 \\
\hline All India & 4.34 & 4.13 & 6.35 & 3.77 & 4.03 & 5.67 & 17.01 & 17.05 & 21.08 \\
\hline
\end{tabular}

Source: U-Dise database

\subsubsection{Higher Education}

Looking at the total enrolments at in Higher Education at all India level, we find that the share of the eight states in the total enrolments is very less and has not increased effectively from 2014-15 to 2016-17. The increase in total enrolment in M.Phil and Ph.D is slightly better than graduate and post-graduate levels. The state of Assam witnessed the highest number of enrolments at graduate, postgraduate, M.phil and Ph.D. The number of enrolments has gone down for the states of Arunachal Pradesh and Manipur at undergraduate level, Nagaland at post-graduate level and Manipur and Tripura at M.Phil and Ph.D levels (see table 2).

Table 2: Enrolments at higher education level (in \%)

\begin{tabular}{|l|l|l|l|l|l|l|l|l|l|l|}
\hline \multirow{2}{*}{ State } & \multicolumn{4}{l}{ Under Graduate } & \multicolumn{2}{l}{ Post Graduate } & \multicolumn{3}{l|}{ M.Phil \& Ph.D } \\
\cline { 2 - 10 } & $2014-15$ & $2015-16$ & $2016-17$ & $2014-15$ & $2015-16$ & $2016-17$ & $2014-15$ & $2015-16$ & $2016-17$ \\
\hline Arunachal Pradesh & 4.90 & 4.60 & 4.11 & 4.85 & 5.73 & 6.22 & 7.52 & 7.75 & 8.39 \\
\hline Assam & 58.37 & 59.52 & 60.89 & 60.68 & 60.28 & 58.48 & 54.54 & 52.05 & 54.40 \\
\hline Manipur & 12.14 & 11.51 & 10.45 & 5.78 & 5.68 & 6.48 & 12.80 & 8.05 & 9.59 \\
\hline Meghalaya & 7.77 & 7.67 & 7.85 & 7.08 & 6.83 & 6.97 & 13.17 & 12.90 & 12.72 \\
\hline Mizoram & 3.14 & 2.97 & 2.86 & 3.36 & 2.77 & 3.18 & 1.63 & 8.65 & 8.16 \\
\hline Nagaland & 3.88 & 3.75 & 3.76 & 6.22 & 4.41 & 4.44 & 2.89 & 2.05 & 3.06 \\
\hline Sikkim & 2.10 & 2.18 & 2.08 & 4.74 & 7.90 & 6.84 & 2.95 & 2.55 & 2.59 \\
\hline Tripura & 7.70 & 7.81 & 7.99 & 7.29 & 6.40 & 7.39 & 4.49 & 6.01 & 1.08 \\
\hline \% Share of NEI & 2.87 & 2.85 & 3.03 & 2.86 & 3.37 & 3.25 & 4.52 & 4.65 & 5.37 \\
\hline
\end{tabular}

Source: Author's estimation using data from AISHE

\section{$\underline{4.2 \text { Employment-unemployment scenario }}$}

\subsubsection{Labour force participation rate}

The labour force participation rate ${ }^{1}$ (LFPR) has fallen in the rural areas of Arunachal Pradesh and Meghalaya with a substantial decline in the participation rate of females (table 3). On the other hand, LFPR has risen in the urban areas of all the states and the rise has been higher for females with the highest being in the states of Sikkim, Assam and Arunachal Pradesh. The top three states with the highest LFPR for females in both the rural and urban areas are Sikkim, Mizoram and Meghalaya. Hence, there is existence of regional inequality in all the states that being higher in Meghalaya, Mizoram and Nagaland across the genders.

\footnotetext{
${ }^{1}$ Is defined as the number of persons/person days in labour force per thousand person/person days (NSSO)
} 
Table3: Labour Force Participation Rate, 1994-2012 (per 1000 persons)

Source: NSS Reports of various rounds

\begin{tabular}{|c|c|c|c|c|c|c|c|c|c|c|}
\hline \multicolumn{11}{|l|}{ Rural } \\
\hline \multirow[t]{2}{*}{ State } & \multicolumn{5}{|l|}{ Male } & \multicolumn{5}{|l|}{ Female } \\
\hline & 1993-94 & 1999-00 & 2004-05 & 2009-10 & 2011-12 & 1993-94 & 1999-00 & 2004-05 & $2009-10$ & 2011-12 \\
\hline $\begin{array}{l}\text { Arunachal } \\
\text { Pradesh }\end{array}$ & 506 & 425 & 505 & 507 & 492 & 410 & 310 & 413 & 295 & 282 \\
\hline Assam & 541 & 546 & 564 & 573 & 564 & 172 & 161 & 216 & 168 & 129 \\
\hline Manipur & 483 & 506 & 531 & 519 & 523 & 311 & 257 & 354 & 221 & 270 \\
\hline Meghalaya & 622 & 559 & 572 & 582 & 529 & 493 & 419 & 480 & 373 & 392 \\
\hline Mizoram & 537 & 563 & 597 & 606 & 599 & 318 & 441 & 441 & 410 & 405 \\
\hline Nagaland & 448 & 532 & 561 & 555 & 590 & 216 & 451 & 511 & 362 & 371 \\
\hline Sikkim & 566 & 519 & 570 & 584 & 586 & 194 & 245 & 323 & 320 & 492 \\
\hline Tripura & 530 & 507 & 607 & 615 & 599 & 136 & 76 & 125 & 235 & 287 \\
\hline All India & 561 & 540 & 555 & 557 & 553 & 330 & 302 & 333 & 265 & 253 \\
\hline \multicolumn{11}{|l|}{ Urban } \\
\hline $\begin{array}{l}\text { Arunachal } \\
\text { Pradesh }\end{array}$ & 525 & 406 & 466 & 454 & 475 & 109 & 110 & 151 & 139 & 335 \\
\hline Assam & 559 & 656 & 591 & 550 & 573 & 124 & 138 & 120 & 97 & 352 \\
\hline Manipur & 456 & 478 & 482 & 497 & 483 & 230 & 225 & 236 & 204 & 343 \\
\hline Meghalaya & 505 & 407 & 470 & 483 & 515 & 196 & 211 & 314 & 210 & 354 \\
\hline Mizoram & 486 & 487 & 491 & 534 & 507 & 266 & 265 & 288 & 267 & 378 \\
\hline Nagaland & 406 & 433 & 479 & 465 & 509 & 105 & 217 & 277 & 224 & 280 \\
\hline Sikkim & 588 & 557 & 564 & 602 & 628 & 148 & 225 & 177 & 274 & 393 \\
\hline Tripura & 529 & 522 & 605 & 612 & 594 & 150 & 81 & 230 & 260 & 341 \\
\hline All India & 543 & 542 & 570 & 559 & 563 & 165 & 147 & 178 & 155 & 363 \\
\hline
\end{tabular}

\subsubsection{Gender Inequality in Employment}

In NER of India, participation of females in employment is higher as compared to others states but there are signs of gender inequality within the NER (see table 4). The inequality, as indicated by the inequality coefficients ${ }^{2}$, is highest in rural and urban areas of Assam (R-0.23,U-0.17 )and Tripura (R-0.41,U-0.22 ) during 2011-12. In Arunachal Pradesh, while the inequality is high in urban areas but a more gender equal workforce exists in the rural areas. Sikkim is another state with a more gender equal workforce in the North Eastern region of India.

Table 4: Gender Inequality in Workforce Participation Rates, 2000-2012

\begin{tabular}{|l|l|l|l|}
\hline State & $1990-00$ & $2004-05$ & $2011-12$ \\
\hline Rural & \multicolumn{4}{l|}{} \\
\hline Arunachal Pradesh & 0.73 & 0.82 & 0.92 \\
\hline Assam & 0.29 & 0.38 & 0.23 \\
\hline Manipur & 0.51 & 0.67 & 0.51 \\
\hline Meghalaya & 0.75 & 0.84 & 0.74 \\
\hline Mizoram & 0.79 & 0.74 & 0.67 \\
\hline Nagaland & 0.85 & 0.92 & 0.62 \\
\hline Sikkim & 0.48 & 0.57 & 0.84 \\
\hline Tripura & 0.14 & 0.15 & 0.41 \\
\hline Urban & \multicolumn{5}{|l|}{} \\
\hline Arunachal Pradesh & 0.25 & 0.32 & 0.28 \\
\hline Assam & 0.21 & 0.20 & 0.17 \\
\hline Manipur & 0.47 & 0.48 & 0.40 \\
\hline Meghalaya & 0.50 & 0.67 & 0.40 \\
\hline
\end{tabular}

\footnotetext{
${ }^{2}$ As measured by the ratio of workforce participation rate of females and males
} 


\begin{tabular}{|l|l|l|l|} 
Mizoram & 0.55 & 0.58 & 0.51 \\
\hline Nagaland & 0.51 & 0.56 & 0.35 \\
\hline Sikkim & 0.39 & 0.31 & 0.44 \\
\hline Tripura & 0.15 & 0.20 & 0.22 \\
\hline
\end{tabular}

Source: Author's estimation using NSS Reports

\subsubsection{Higher Education and Employment}

Since an increasing share of jobseekers is with graduate and above degrees, we take workforce participation rate ${ }^{3}$ (WPR) at graduate level to analyse the employability of higher education graduates in the states. The trend analysis shows that WPR in 2011-12 has fallen for almost all the states in both rural and urban areas since 1993-94 and it is also higher in rural areas than urban areas (see figure 2). A marginal increase is recorded only in the states of Assam (rural), Sikkim (rural \& urban).

Figure 2: WPR at graduate level of education
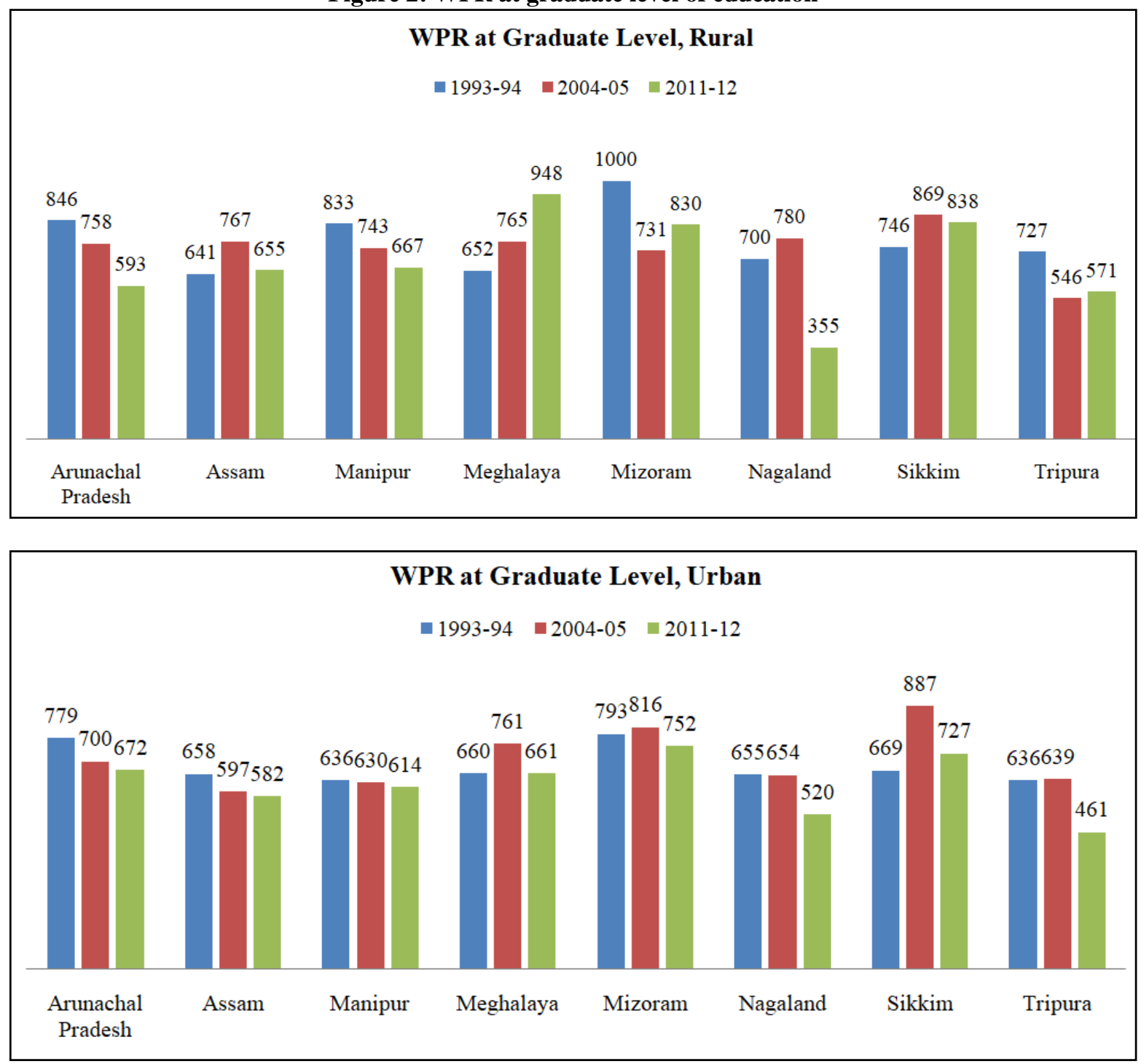

Source: NSS reports of various rounds

\subsubsection{Sectoral Employment}

The top three sectors that employ the maximum share of working population in rural areas are agriculture, construction and public administration \& community services (see figure 3 ). While in urban areas, the top three sectors are public administration \& community services, wholesale and agriculture. It is clearly visible that agriculture is the primary sector of employment generation in the NER. The high growth sectors identified by planning commission in India, which employed a sizeable proportion of the graduate employees, are

\footnotetext{
${ }^{3}$ Is defined as percentage of total workers to the total population (NSSO) 
Banking, Financial services and Insurance (BFSI), Construction or real estate and Organised Retail (Khare, 2014) while in the NER, these sectors do not absorb a great share of the working population. Though, it is only the state of Tripura where the rural region is seen to have a high working population in the construction sector.

Figure 3: Sectoral Distribution of Working Population, 2011-12

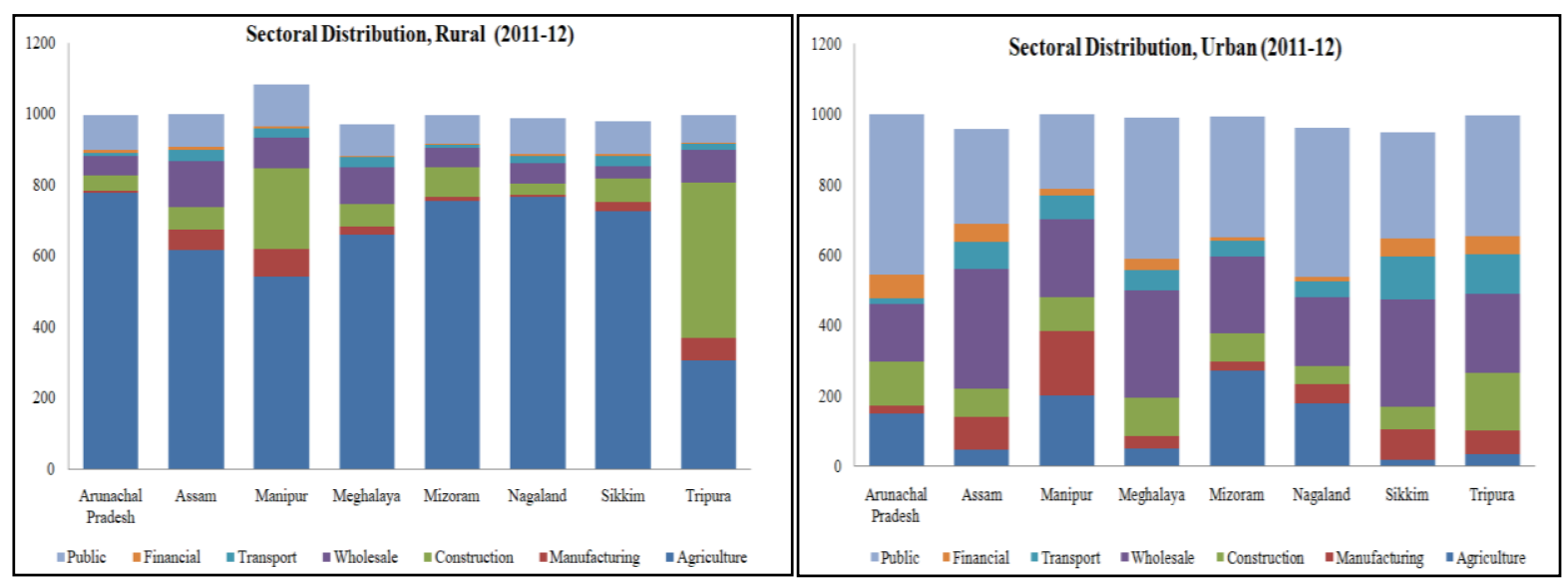

Source: NSS reports of various rounds

\subsubsection{Social transformation and the better performing states}

The above analysis helps us identify the top and bottom performing states as per the various indicators of social transformation. Education leads to employment and employment brings about a social change in the society. While employment of graduates\& above level of education is an indicator of skill development and employability in the state, female labour force participation explains if women are becoming a productive asset of the state or not and if there is an existence of gender inequality in the society. The states of Nagaland, Arunachal Pradesh and Tripura (see table 5) are lagging in the process of social transformation as seen from the lens of education and employment creation.

Table 5: Performance of states

\begin{tabular}{|c|c|c|}
\hline Social Transformation: Indicators & Top 3 States & Bottom 3 States \\
\hline Dropout Rate at Secondary level, 2016-17 & Manipur, Sikkim, Assam & $\begin{array}{l}\text { Mizoram, Arunachal Pradesh, } \\
\text { Nagaland }\end{array}$ \\
\hline $\begin{array}{l}\text { Enrolments at graduate \& above, 2014-15 to } \\
2016-17\end{array}$ & Assam, Manipur, Tripura & Sikkim, Mizoram, Nagaland \\
\hline LFPR, 2017-18 & Meghalaya, & $\begin{array}{l}\text { Nagaland, Arunachal Pradesh, } \\
\text { Tripura }\end{array}$ \\
\hline FLFPR, 2017-18 & Meghalaya, & Tripura, Assam, Arunachal Pradesh \\
\hline WPR for graduates \& above, $2011-12$ & $\begin{array}{l}\text { Meghalaya, } \\
\text { Mizoram }\end{array}$ & $\begin{array}{l}\text { Nagaland, } \\
\text { Pradesh }\end{array}$ \\
\hline
\end{tabular}

Source: Author's understanding based on analysis

\section{CONCLUDING REMARKS}

For individuals, their employability quotient is both a resultant and a determining factor of the quality of the higher education sector. In today's fast growing globalizing economy, a country's competitiveness and movement up the value chain beyond simple production processes and products is highly a function of its quality of higher education and training (Schwab, 2010-11). Therefore, the linkages between higher education and employment in the potential sectors should be strengthened. Social transformation will eventually trickle down to all the sectors of the society by engaging a higher number of highly educated graduates across regions and genders.

Inclusive growth and development will take place when inclusivity is placed at educational level which means eradication of all kinds of disparities arising out of region, gender and caste. Inclusivity in employment will be achieved when all the sections of the economy participate in the productive sectors of industries with a greater potential to yield economic benefits. This shall further be augmented with skilled employability and inclusion. 
Hence, we can conclude that education and employment are the routes to social transformation and the process is lagging in the identified states of NER. Therefore, corrective measures and policy initiatives should be taken to uplift these states by speeding up the process of social transformation.

\section{REFERENCES}

[1] Bank, T. W. (2007). Development and Growth in North East India: The Natural Resources, Water, and Environment Nexus, Strategy Report. The International Bank for Reconstruction and Development.

[2] (2015). Basic Statistics of North Eastern Region. Shillong: North Eastern Council Secretariat.

[3] Chapter IV: North East India: Social, Political, Economic and Secuirty Perspectives .

[4] Das, K. S. (2018, January). Employment in North East India: An Investigation. Manpower Journal

[5] Dhar, D. S. (2015). Gender Inequality in Education, Health and Employment in North East India. International Journal of Humanities \& Social Sciences Studies , 111-116.

[6] Dore, R. (1976). The Diploma Disease: Education, Qualification and Development. London: George Allen \& Unwin.

[7] Glewwe, P., \& M., K. (2006). School, Teachers, and education outcomes in developing countries. In E. A. Hanushek, \& F. Welch (Eds.), Handbook of the economics of education

[8] Khare, M. (2014). Employment, Employability and Higher Education in India: The Missing Links. SAGE, 39-62.

[9] Kumar, N., \& Chakraborty, S. (2013, March). Higher Education Scenario of the North-Eastern India. Indian Journal of Research , 78-80.

[10] Lahoti, R., \& Swaminathan, H. Economic Growth and Female Labour Force Participation in India. Centre for Public Policy.

[11] Mincer, J. (1974). Schooling and earnings: Schooling, experience and earnings. New York: Columbia University Press.
[12] Nayar, U. S. (2004). Education for Social Transformation: A Collective Step Forward. The Journal of Family Welfare , 9-14.

[13] NITI Aayog, G. (2019). Human Resource Profile India Yearbook 2019 Delhi: National Institute of Labour Economics Research and Development.

[14] Office, N. S. (2019). Periodic Labour Force Survey (PLFS). Delhi: MOSPI.

[15] Organization, N. S. (2014). Employment and Unemployment Situation in India, NSS 68th Round. New Delhi: MOSPI.

[16] Organization, N. S. (2006). Employment and Unemployment Situation in India, NSS 61st Round. MOSPI.

[17] Psacharopoulos, R. L. The Screening Hypothesis and Returns to Education.

[18] S., M. Z., Lahiri-Dutt, K., Lockie, S., \& Pritchard, B. (2017). Reconsidering Women's Work in Rural India Analysis of NSSO Data, 2004-05 and 201112. Economic and Political Weekly, Vol. L II no.1 .

[19] Sanghi, S., Srija, A., \& Vijay, S. S. (2015). Decline in Rural Labour Force Participation in India: A Relook into the causes. The Journal for Decision Makers, SAGE , 255-268.

[20] Schwab, K. (2010-11). Global competitiveness report. Geneva: World Economic Forum.

[21] Schultz, T. P. (1994). Human Capital Investment in Women and Men: Micro and Macro

[22] Schultz, T. W. (1961). Investment in Human Capital (Vol. 51). The American Economic Review .

[23] Sharma, H. I. (2015). Rural Employment Scenario in North East India Economic \& Political Weekly, 61-65.

[24] United Nations Economic Commission for Europe, U. (2015). Handbook on Measuring Quality of Employment, A statistical framework, Prepared by the Expert Group on Measuring Quality of Employment. New York, Geneva.

\section{AUTHORS}

First Author - Ms. Sonam Arora, Ph. D. Scholar, National Institute of Educational Planning and Administration, India 110016, E-mail: sonamarora.nuepa@gmail.com, sonamarora@niepa.ac.in 